\title{
Lentinula edodes based GIS mapping, biometabolites and antiinflamatory activity of wild edible mushrooms from tropical 'sacred grove' forests of Meghalaya, India
}

\author{
Polashree Khaund \& S. R. Joshi* \\ Microbiology Laboratory, Department of Biotechnology \& Bioinformatics, North-Eastern Hill University, \\ Shillong-793022, Meghalaya, India; polashree@yahoo.com; srjoshi2006@yahoo.co.in*
}

Received 30-VII-2015. Corrected 20-VIII-2015. Accepted 21-IX-2015.

\begin{abstract}
The biodiversity rich state of Meghalaya, India located in the realms of mega-biodiversity hotspots, is home to numerous species of wild edible macrofungi that are used extensively by the mycophillic ethnic population, as a part of their traditional cuisine and medicine systems. However, habitat loss, due to deforestation and climate change, is destroying the natural population of these mushrooms, depleting their availability to the local communities. In the present investigation, a GIS guided habitat search, using Lentinula edodes as a representative species, was used in mapping the habitats of wild edible macrofungi of the study region. Sampling of around 4000 specimens per distinct morphological type available in the traditional markets and "sacred grove" forests indicated presence of ten common genera, belonging to nine different families of wild edible mushrooms. Nutritional profiling of the representative species Lentinula edodes was carried out by evaluation of its moisture, total fat, crude protein and carbohydrates contents by standard methods. Similarly, bioactive components determination was performed by estimation of total phenols, flavonoids, ascorbic acid, $\beta$-carotene and lycopenes. Bioactivity of the mushrooms extracts was studied using the DPPH radical scavenging and Human Red Blood Cell (HRBC) membrane stabilization assays. The present investigation successfully attempted to explore remote sensing technologies and GIS (Geographic Information System) based system to predict the natural habitats of wild edible mushrooms of Meghalaya, India which we believe will lead to the generation of a mushroom specific non-wood forest resource mapping system in the near future. Results of nutritional profiling and biological activity studies on the representative species of wild edible mushrooms from the studied region revealed that it is a rich source of essential nutrients and antioxidants. Rev. Biol. Trop. 64 (1): 247-257. Epub 2016 March 01.
\end{abstract}

Key words: wild edible mushrooms, characterization, ethnic tribes, GIS based system, mapping, "sacred grove" forests, Lentinula edodes, biometabolites, anti-inflammatory activity.

Wild edible mushrooms (WEM) have been regarded by most ancient civilizations as "the foods of the Gods" (Hobbs, 1995). Being low in caloric value $(300-390 \mathrm{Kcal} / 100 \mathrm{~g}$ dry wt) and fat content but with high protein, they are considered as 'delight of diabetic patients' and are now being regarded as one of the world's greatest untapped resources of nutritious and palatable food for the future (Harsh \& Joshi, 2008). Many cultures have built-up a practical knowledge of edible and poisonous mushrooms (Hobbs, 1995). In the state of Meghalaya in India, the practice of collecting mushrooms from the forests and selling them in the local markets has been a long established tradition amongst the ethnic tribes. The forests of Meghalaya can be broadly grouped into tropical, subtropical and temperate types with the vegetations belonging to tropical evergreen, tropical semi-evergreen, tropical moist deciduous, subtropical broad leaved, subtropical pine and temperate forest types, grasslands and savannas (Tripathi, Pandey, Barik, \& Kumar 2005). Some of these forests known as 'sacred forests' or 'sacred groves,' represent areas with high species richness and constitute a 
major portion of the community forests which are left undisturbed since time immemorial due to religious beliefs, in spite of the everincreasing anthropogenic exploitation (Bhagobaty \& Joshi, 2011). Wild edible mushrooms are collected from the forests of the region based on ethno-mycological knowledge of the local tribal societies. However, the survey and collection of mushrooms has always been a difficult task owing to the hilly terrain coupled with the high rainfall patterns. There has been constant decline over the years in the availability of the varieties of wild edible mushrooms in the traditional rural markets of the region. The scientific documentation, characterization and evaluation of the nutritional properties of the available mushrooms of the region have been scarce (Barua et al., 1998; Agrahar-Murugkar \& Subbulakshmi, 2005).

The present study was attempted to predict the habitats of wild edible mushrooms based on the principles of a GIS based expert system, and at evaluating the functional properties of these novel medicinal mushrooms as a nonwoody forest resource of the ethnic tribal communities of the region.

\section{MATERIALS AND METHODS}

The East Khasi hills constitute the most populated district among the seven districts of the State of Meghalaya (Fig. 1). The district occupies an area of $2748 \mathrm{Km}^{2}$ and lies between $25^{\circ} 07^{\prime \prime} \& 25^{\circ} 41^{\prime \prime} \mathrm{N}$ and $91^{\circ} 21^{\prime \prime} \& 92^{\circ} 09^{\prime \prime} \mathrm{E}$

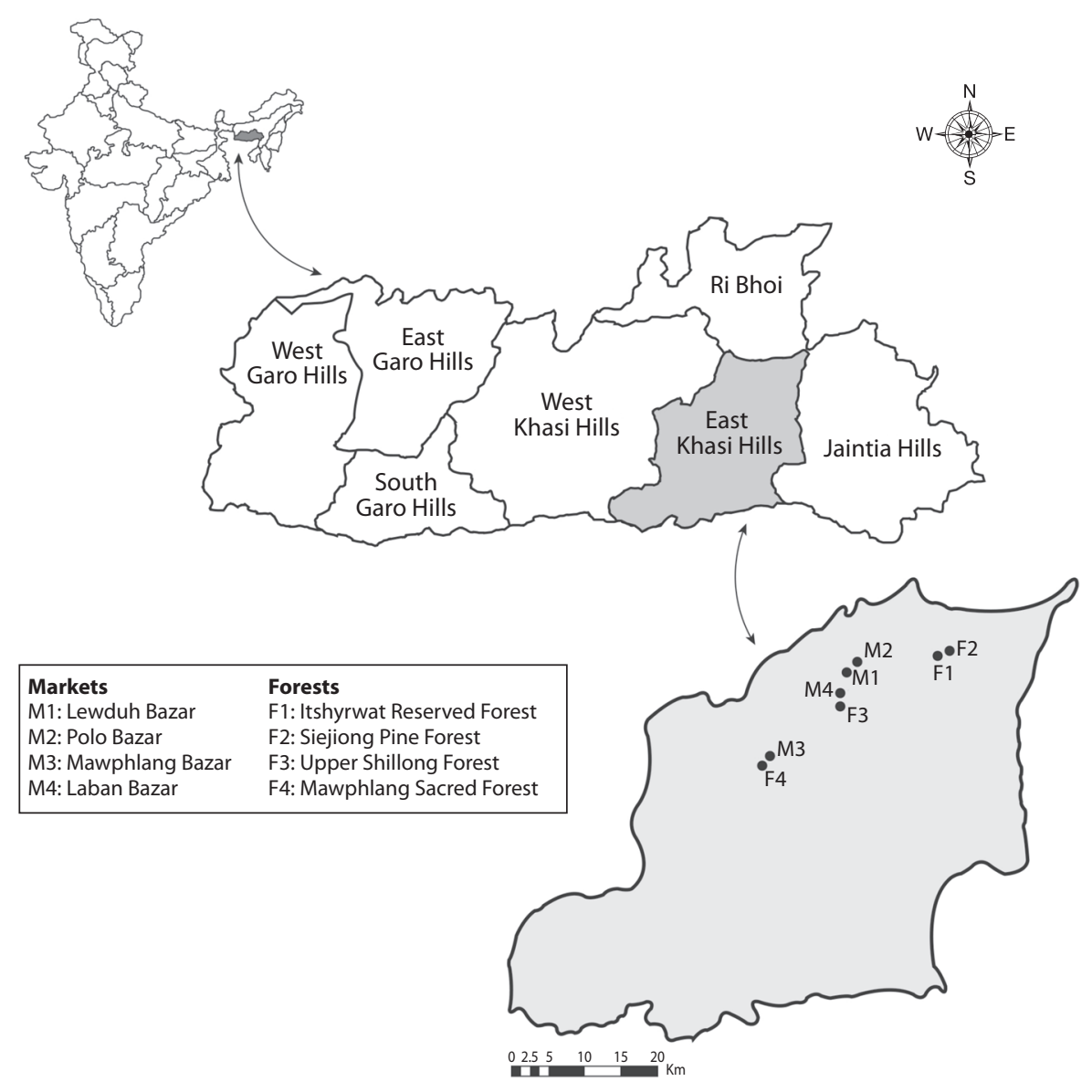

Fig. 1. Mushrooms collection sites (forests and markets) in the East Khasi Hills district of Meghalaya, India. 
TABLE 1

Markets and forests in the East Khasi hills district of Meghalaya from which the mushrooms were collected during the study period

\begin{tabular}{|c|c|c|c|}
\hline Iewduh Bazar & $25^{\circ} 34^{\prime} 36.9^{\prime \prime} \mathrm{N} 91^{\circ} 52^{\prime} 34.7^{\prime \prime} \mathrm{E}$ & Itshyrwat Reserved Forest & 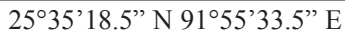 \\
\hline Polo Bazar & $25^{\circ} 34^{\prime} 53.3^{\prime \prime} \mathrm{N} 91^{\circ} 53^{\prime} 15.0^{\prime \prime} \mathrm{E}$ & Siejiong Pine Forest & $25^{\circ} 35^{\prime} 41.8^{\prime \prime} \mathrm{N} 91^{\circ} 58^{\prime} 18.1^{\prime \prime} \mathrm{E}$ \\
\hline Mawphlang Bazar & 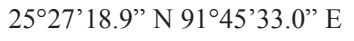 & Upper Shillong Forest & $25^{\circ} 33^{\prime} 18.5^{\prime \prime} \mathrm{N} 91^{\circ} 52^{\prime} 10.3^{\prime \prime} \mathrm{E}$ \\
\hline Laban Bazar & 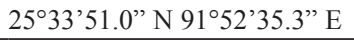 & Mawphlang Sacred Forest & $25^{\circ} 26^{\prime} 74.5^{\prime \prime} \mathrm{N} 91^{\circ} 44^{\prime} 91.2^{\prime \prime} \mathrm{E}$ \\
\hline
\end{tabular}

(Tripathi et al., 2005). Forests occupy 35.34 $\%$ of the land area and have been exploited over the years for natural resources such as timber, medicinal plants, fodder, fuel wood and food resources like mushrooms (Tripathi et al., 2005).

Thematic services of Bhuvan (Geoportal of Indian Space Research Organisation, showcasing Indian imaging capabilities in Multisensor, Multi-platform and Multi-temporal domain), available at http://bhuvan-noeda.nrsc. gov.in/theme/thematic/theme.php, was used to obtain the Land Use Land Cover (LULC) data of the areas near which the local markets (Table 1) selling the mushrooms were located. Land Use Land Cover (LULC-50K) datasets with an overall accuracy ranging from 79 $\%$ (for agro-horticulture) to $97 \%$ (for water bodies) of the area near the capital city of Shillong in Meghalaya State, India, from two timeframes i.e. 2005-06 and 2011-12 (http:// bhuvan-noeda.nrsc.gov.in/theme/thematic/ theme.php, accessed 04/01/2013) were visualized to study the changes of evergreen and semi-evergreen forest cover. Habitat information of the wild edible mushrooms exhibiting ecto-mycorrhizal symbiosis with trees or saprotrophic relationships with wood as reported in previous literature (Ogawa, 1976; Sabota, 1996; Joshi et al., 2013) was correlated with the forest cover patterns available in the LULC datasets. Additional information on the annual rainfall distribution and agro-climatic zone characterization (APIB, $2013 \mathrm{http} / / /$ megapib. nic.in) obtained from the Agriculture Planning and Information Bank (APIB) available at http://megapib.nic.in/, of the East Khasi hills district of Meghalaya along with the traditional mushroom harvesting knowledge of the ethnic tribes (Khaund \& Joshi, 2013), were taken into consideration to arrive at the best possible locations for the mushroom specimens in their wild original habitats in the forests (geographical coordinates in Table 1).

Mushroom samples were collected from the forests and the local markets (Fig. 1; Table 1) in the East Khasi hills district of Meghalaya during the study period from April to October, 2011. Sampling of around 4000 specimens per distinct morphological type, and a total of four rounds of sampling were carried out during the entire course of the study period. The samples were wrapped in aluminium foil and stored in sterile containers prior to their transport to the laboratory for preservation and identification. Care was taken to avoid distortion of the fleshy fungi. The collected specimens were assigned a unique identifier accession number and were stored in the culture collection of the parent department in $4 \%$ formaldehyde (Tanti et al., 2011). Alternatively, the specimens were also oven dried using protocols modified from Gezer et al. (2006) at $80{ }^{\circ} \mathrm{C}$ for five days, wrapped in aluminium foil and stored at -20 ${ }^{\circ} \mathrm{C}$ in labelled containers for further analysis. A part of the dried sample was used for the preparation of crude extracts. The morphological characters of the fruiting bodies were noted following the standard manuals for mushroom identification (Svrcek \& Coxon, 1975; Purkayastha \& Chandra, 1985) and mycokeys available at www.mushroomexpert.com and www. mycokey.com.

Lentinula edodes sample preparation and estimation of bioactive compounds: One of the most widely harvested and used mushroom specimen is L. edodes (Accession no: 
PKSR14). In this study, even though samples were taken for different species in the area, this study selected this species as a representative mushroom for further analysis, to evaluate the nutritional and medicinal properties with relevance to its demand, common availability and health benefits to the ethnic tribes. For this, dried mushroom samples were ground into coarse powder ( $20 \mathrm{mesh})$. A total of $10 \mathrm{~g}$ of the powdered sample were extracted by stirring with $100 \mathrm{~mL}$ ethanol at $30{ }^{\circ} \mathrm{C}$ at $150 \mathrm{rpm}$ for $24 \mathrm{~h}$ and filtered through Whatman No. 4 filter paper. The residue was then, extracted with two additional volumes of $100 \mathrm{~mL}$ of ethanol as described above. The combined ethanolic extracts were then rotary evaporated at $40{ }^{\circ} \mathrm{C}$ to dryness, redissolved in ethanol for the antioxidant assays to a final concentration of $10 \mathrm{mg} /$ $\mathrm{mL}$ and stored at $4{ }^{\circ} \mathrm{C}$ for further use (Gezer et al., 2006).

Total phenolic content: The total phenolic compounds (TPC) in the mushroom extract were estimated by a colorimetric assay (Singleton \& Rossi, 1965) with some minor modifications. For this, $1 \mathrm{~mL}$ of Folin Ciocalteu's phenol reagent was added to $1 \mathrm{~mL}$ of sample and after $3 \mathrm{~min}, 1 \mathrm{~mL}$ of saturated sodium carbonate solution was added to the mixture, and the volume was made to $10 \mathrm{~mL}$ with double distilled water. The reaction was kept in the dark for $90 \mathrm{~min}$, after which the absorbance was read at $725 \mathrm{~nm}$ against ethanol as blank UV/Visible Spectrophotometer (Cecil, England). Gallic acid (0.01-1 mg/mL) was used as standard.

Total flavonoids: Flavonoid concentration was determined using standard procedures (Park et al., 1997). The mushroom extract $(1 \mathrm{~mL})$ was diluted with $4.3 \mathrm{~mL}$ of $80 \%$ aqueous ethanol and $0.1 \mathrm{~mL}$ of $10 \%$ aluminum nitrate and $0.1 \mathrm{~mL}$ of $1 \mathrm{M}$ aqueous potassium acetate were added. After $40 \mathrm{~min}$ at room temperature, the absorbance was measured at $415 \mathrm{~nm}$ with a UV/ Visible Spectrophotometer (Cecil, England) against ethanol as blank. Total flavonoid concentration was calculated using quercetin as standard $(0.01-0.5 \mathrm{mg} / \mathrm{mL})$.

Ascorbic acid: Ascorbic acid was determined according to the method of Klein \& Perry (1982). The dried ethanolic extract (100 $\mathrm{mg}$ ) was extracted with $10 \mathrm{~mL}$ of $1 \%$ metaphosphoric acid for $45 \mathrm{~min}$ at room temperature and filtered through Whatman No.4 filter paper. The filtrate $(1 \mathrm{~mL})$ was mixed with 9 $\mathrm{mL}$ of 2, 6-dichloroindophenol, and the absorbance was measured within $30 \mathrm{~min}$ at $515 \mathrm{~nm}$ with a UV/Visible Spectrophotometer (Cecil, England) against a double distilled water blank. Content of ascorbic acid was calculated using L-ascorbic acid as standard (0.01-0.5 mg/mL).

$\beta$-carotene and lycopene: $\beta$-carotene and lycopene were determined according to the method of Nagata \& Yamashita (1992). The dried ethanolic extract (100 mg) was vigorously shaken with $10 \mathrm{~mL}$ of acetone-hexane mixture (4:6) for $1 \mathrm{~min}$ and filtered through Whatman No.4 filter paper. The absorbance of the filtrate was measured at 453, 505, 645 and $663 \mathrm{~nm}$ with a UV/Visible Spectrophotometer (Cecil, England) against double distilled water blank. Content of $\beta$-carotene and lycopene was calculated according to the following equations:

$$
\begin{gathered}
\text { Lycopene }(\mathrm{mg} / 100 \mathrm{~mL})= \\
-0.0458 \mathrm{~A} 663+0.372 \mathrm{~A} 505-0.0806 \mathrm{~A} 453 \\
\beta \text {-carotene }(\mathrm{mg} / 100 \mathrm{~mL})= \\
0.216 \mathrm{~A} 663-0.304 \mathrm{~A} 505+0.452 \mathrm{~A} 453 .
\end{gathered}
$$

added. The mixture was shaken vigorously, left to stand for 30 minutes.

Anti-oxidant potential of the fungal extract by radical scavenging activity analysis: The capacity of the crude macrofungal extract to scavenge the 'stable' free radical DPPH was monitored according to the method of Blois (1958) with some modifications. To $100 \mu \mathrm{L}$ of the extract in different concentrations, $5 \mathrm{~mL}$ of $0.1 \mathrm{mM}$ ethanolic solution of DPPH was min in the dark, and the decrease 
in absorbance was measured at $517 \mathrm{~nm}$ using a UV/ Visible Spectrophotometer (Cecil, England). BHT was used as positive control and the blank used was ethanol. The radical scavenging activity was measured as a decrease in absorbance of DPPH and calculated as:

DPPH scavenging effect $(\%)=(\mathrm{Ad}-\mathrm{As} / \mathrm{Ad}) \times 100$,

where Ad is the absorbance of the control reaction containing DPPH solution, and As, the absorbance in presence of the extract or BHT.

Nutritional composition analysis: The mushroom sample was analysed for chemical composition (moisture, protein, fat, carbohydrates and ash) using the AOAC procedures (1995). The crude protein content $\left(\mathrm{N}^{*} 4.38\right)$ of the samples was estimated by the macro Kjeldahl method; the crude fat was determined by extracting a known weight of powdered mushroom sample with petroleum ether, using a Soxhlet apparatus; the ash content was determined by incineration at $600 \pm 15^{\circ} \mathrm{C}$; reducing sugars were determined by DNS (dinitrosalicylic acid) method. Total carbohydrates were calculated as follows:

$$
\begin{gathered}
\text { Total carbohydrates }= \\
100-(\mathrm{g} \text { moisture }+\mathrm{g} \text { protein }+\mathrm{g} \text { fat }+\mathrm{g} \text { ash }) .
\end{gathered}
$$

Total energy was calculated according to the following equation:

$$
\begin{gathered}
\text { Energy }(\mathrm{kcal})= \\
4 \times(\mathrm{g} \text { of protein }+\mathrm{g} \text { of carbohydrate })+9 \times(\mathrm{g} \text { of lipid }) .
\end{gathered}
$$

Evaluation of anti-inflammatory properties through the human Red Blood Cell (HRBC) membrane stabilization test: Institutional ethical guidelines of North-Eastern Hill University, Shillong, Meghalaya, India, were followed. Fresh whole human blood $(10 \mathrm{~mL})$ was collected from a healthy human volunteer who had not taken any anti-inflammatory drugs for two weeks prior to the experiment; sample was transferred to heparinised centrifuge tubes. The tubes were centrifuged at $3000 \mathrm{rpm}$ for $10 \mathrm{~min}$ and were washed three times with equal volume of normal saline. The volume of blood was measured and reconstituted as $10 \% \mathrm{v} / \mathrm{v}$ suspension with normal saline (Govindapppa et al., 2011). The reaction mixture consisted of $2 \mathrm{~mL}$ of hypotonic saline $(0.25 \% \mathrm{w} / \mathrm{v} \mathrm{NaCl}), 1 \mathrm{~mL}$ of $0.15 \mathrm{M}$ phosphate buffer (pH 7.4), $0.5 \mathrm{~mL}$ of test solution (10 $\mathrm{mg} / \mathrm{mL}$ ) in normal saline and $0.5 \mathrm{~mL}$ of $10 \%$ HRBC in normal saline. For control, $0.5 \mathrm{~mL}$ of normal saline was used instead of test solution. Aspirin was taken as a standard drug $(1 \mathrm{mg} /$ $\mathrm{mL})$. All the centrifuge tubes containing reaction mixture were incubated in water bath at $56{ }^{\circ} \mathrm{C}$ for $30 \mathrm{~min}$. At the end of the incubation, the tubes were cooled under running tap water. The reaction mixture was centrifuged at 3000 rpm for $5 \mathrm{~min}$ and the absorbance of the supernatants was taken at $560 \mathrm{~nm}$ with a UV/Visible Spectrophotometer (Cecil, England) against buffer as blank. The experiment was performed in triplicates for all the test samples. Percent membrane stabilization activity was calculated by the formula given below:

$$
\% \text { Inhibition of haemolysis }=(\mathrm{Ac}-\mathrm{As} / \mathrm{Ac}) \times 100
$$

where $A c$ is the absorbance of the reaction mixture without the extract or Aspirin, and As is the absorbance in the presence of extract or Aspirin.

\section{RESULTS}

Habitat search of wild edible mushrooms using GIS applications: The observations of the Land Use and Land Cover datasets of the study area i.e. Shillong region in the East Khasi Hills District of the state of Meghalaya in Bhuvan for two timeframes i.e. 2005-06 and 2011-12, reveals that the area classified as Urban has increased from 2005 to 2012 (http://bhuvan-noeda.nrsc.gov.in/theme/thematic/theme.php, accessed 04/01/2013). There is also a reduction and change in the areas classified as Evergreen and Semi-evergreen forests during the same time span (http://bhuvan-noeda.nrsc.gov.in/theme/thematic/theme. php Dataset: Meghalaya District East Khasi 
Hills). Correlation of the habitat information of ecto-mycorrhizal or saprotrophic wild edible mushrooms (WEM) using Lentinula edodes as a representative genus with the forest cover patterns available in the LULC datasets helped in the selection of the forest areas likely to harbour WEM (Table 1). The annual rainfall distribution pattern of Meghalaya reveals the present study area (Table 1; http://bhuvan-noeda.nrsc. gov.in/theme/thematic/theme.php) to be having low to medium rainfall annually (APIB, 2013 http://megapib.nic.in/agro_atlas_rd.htm ). The study area is also shown to be characterized into the Cold, Moisture (C, M) surrounded by the Cold, Wet $(\mathrm{C}, \mathrm{W})$ agro-climatic zone in its periphery (APIB, 2013 http://megapib.nic.in/ agro_atlas_azm.htm). This additional information obtained from the Agriculture Planning and Information Bank of the East Khasi Hills District of Meghalaya was in agreement with the type of climatic condition that favoured the growth of ecto-mycorrhizal and saprotrophic mushrooms in the presence of evergreen tree cover.

Morphological characteristics: Based on the comparison of the morphological features of the collected specimens with standard mushroom identification manuals and mycokeys, the specimens were tentatively identified (Table 2). Out of the ten different specimens, the sample PKSR14 (Lentinula edodes) was further subjected to biochemical analysis based on its demand and availability in the forest and local markets.

Content of bioactive compounds: The major bioactive components of the extract were the total phenolic content (TPC) which was $10.08 \pm 0.13 \mathrm{mg} / \mathrm{g}$. The total flavonoid content was found to be $0.91 \pm 0.16 \mathrm{mg} / \mathrm{g}$. Ascorbic acid was found in small amounts $(0.72 \pm 0.04 \mathrm{mg} / \mathrm{g})$, and $\beta$-carotene $(6.00 \pm 0.37 \mu \mathrm{g} / \mathrm{g})$ and lycopene $(2.12 \pm 0.27 \mu \mathrm{g} / \mathrm{g})$ were found in vestigial amounts $(<10 \mu \mathrm{g} / \mathrm{g})$.

Estimation of anti-oxidant potential: Scavenging effects on DPPH radicals increased with the increase in concentrations of the extract and BHT (Fig. 2). At $10 \mathrm{mg} / \mathrm{mL}$ the sample extract of the isolate Lentinula edodes PKSR14 scavenged up to $61.33 \%$ of the free radicals showing effective radical scavenging capacity (Fig. 2).

Nutrient composition: The results of the nutrient composition assays of Lentinula edodes PKSR14 revealed it to be rich in carbohydrates and total energy. The carbohydrate content was determined to be $58.69 \pm 4.35$ $\mathrm{g} / 100 \mathrm{~g}$, while the total energy value was estimated to be $298.63 \pm 17.92 \mathrm{Kcal}$. The total fat and crude protein content were found to be $3.54 \pm 0.06 \mathrm{~g} / 100 \mathrm{~g}$ and $8.00 \pm 0.57 \mathrm{~g} / 100 \mathrm{~g}$,

TABLE 2

Identity of the collected wild edible mushroom (WEM) specimens

\begin{tabular}{lll}
\hline PKSR1 & Gomphus floccosus (Schw.) Singer & Order: Phallales; Family: Gomphaceae \\
PKSR3 & Lactarius deliciosus (L. ex Fr.) S. F. Gray & Order: Russulales; Family: Russulaceae \\
PKSR4 & Craterellus odoratus (Schwein.) Fr. & Order: Cantharellales Family: Cantharellaceae \\
PKSR5 & Lactarius volemus (Fr.) Fr. & Order: Russulales; Family: Russulaceae \\
PKSR7 & Cantharellus cibarius Fr. & Order: Cantharellales; Family: Cantharellaceae \\
PKSR8 & Tricholoma saponaceum (Fr.) P. Kumm. & Order: Agaricales; Family: Tricholomataceae \\
PKSR10 & Inocybe sp. & Order: Agaricales; Family: Inocybaceae \\
PKSR11 & Laccaria lateritia Malençon & Order: Agaricales; Family: Hydnangiaceae \\
PKSR12 & Albatrellus sp. & Order: Polyporales; Family: Albatrellaceae \\
PKSR13 & Ramaria sp. & Order: Gomphales; Family: Gomphaceae \\
PKSR1CF & Clavulina sp. & Order: Gomphales; Family: Clavulinaceae \\
PKSR14 & Lentinula edodes (Berk.) Pegler & Order: Agaricales; Family: Marasmiaceae \\
\hline
\end{tabular}




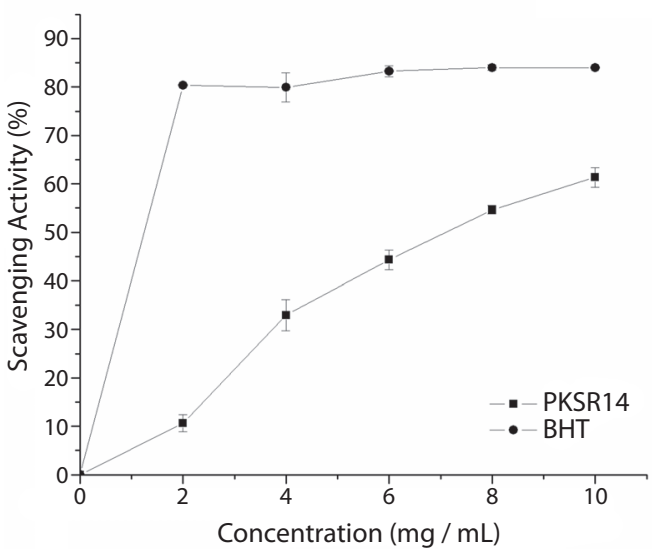

Fig. 2. Scavenging activity (\%) on DPPH radicals of ethanolic extracts from Lentinula edodes (PKSR14). Each value is expressed as mean $\pm \operatorname{SEM}(n=3)$.

respectively. The moisture content was found to be $23.33 \pm 4.37 \mathrm{~g} / 100$, while the ash content was determined to be $6.43 \pm 0.23 \mathrm{~g} / 100 \mathrm{~g}$.

Evaluation of anti-inflammatory properties: The inhibition of HRBC membrane lysis i.e, stabilization of HRBC membrane was taken as a measure of the anti inflammatory activity of the extract. Ethanolic extract of Lentinula edodes PKSR14 showed effective anti-inflammatory activity of $50 \pm 4.40 \%$ at 10 $\mathrm{mg} / \mathrm{mL}$ concentration. The standard drug Aspirin showed higher anti-inflammatory activity of $81.66 \pm 0.57 \%$ at $10 \mathrm{mg} / \mathrm{mL}$ concentration.

\section{DISCUSSION}

The habitats of most wild edible mushrooms in Meghalaya are undergoing changes due to urbanization, deforestation and climate change leading to a reduced availability of these mushrooms in the traditional rural markets (Khaund \& Joshi, 2013). These observations are corroborated by visualization of the land use and land cover patterns of the region in Bhuvan. Although a variety of spatial distribution models have been applied to map many different plants (Franklin, 1998; Iverson et al., 1999; Austin, 2002; Zaniewski et al., 2002; Peltoniemi, 2005), similar reports for mushrooms have been very scarce. In the present study, the principles of the GIS based expert system was used to successfully predict the habitats of the wild edible ecto-mycorrhizal and saprotrophic mushrooms sold extensively in the rural markets (Khaund \& Joshi, 2013). The prediction ability of the GIS based approach was validated by field surveys for collection of specimens for the present study.

Kranabetter et al., (2002) using a similar approach estimated the habitat of American matsutake (Tricholoma magnivelare) using aerial photos in collaboration with summarized ecological descriptions. Yang et al., (2006), attempted to model the spatial distribution of matsutake mushrooms at a fine scale in a more complex environment i.e., mountainous terrains of Yunnan in China, using a logistic regression and GIS expert system. They reported that the overall mapping accuracy of their GIS expert system was slightly better than the logistic regression approach $(70.37 \%$ versus $65.43 \%$ ). Further, they observed that, unlike the logistic regression model, developing the GIS expert system required no field-based samples. Presently, efforts are on to incorporate local mycological knowledge as gathered in the previous study (Khaund \& Joshi, 2013) in decision making process of a GIS expert system (Skidmore et al., 1996) for creating a parsimonious model of mushroom distribution that will form the part of a mushroom specific non-wood forest resource mapping and search system for Meghalaya, India.

Phenolics exhibit a plethora of antibacterial, anti-inflammatory, antihyperglycemic and antioxidant actions (Yaltirak et al., 2009; Palanisamy et al., 2011). The total phenolics act as strong antioxidants and free radical scavengers that help in chelation of heavy metals along with interaction with enzymes, adenosine receptors and biomembranes (Saija et al., 1995). There are reports on the total phenolic content (TPC) and total flavonoid content (TFC) in the crude extract of Lentinula edodes (Cheung et al., 2003; Reis et al., 2012). In the present study, the TPC (10.08 mg GAE/g extract) of Lentinula edodes PKSR14 was higher than that 
obtained for methanolic extracts of Chinese samples (8.51 mg GAE/g extract) (Cheung et al., 2003). Ascorbic acid and carotenoids such as $\beta$-carotene and lycopene are known to be potent naturally occurring antioxidants (Sies \& Stahl, 1995; Rao \& Agarwal, 1999; Wilson, 2005). Similar concentrations of ascorbic acid, $\beta$-carotene and lycopene in wild edible mushrooms have been reported previously (Barros et al., 2007; Barros et al., 2008a, b). The high content of total phenols in the L. edodes PKSR14 extracts might account for the better results found in their radical scavenging effect on DPPH radicals (Ferreira et al., 2007).

In a similar study on the antioxidant properties of edible mushroom extracts from China, Cheung et al. (2003) reported the DPPH radical scavenging activity of Lentinula edodes to be $29.40 \%$ at a concentration of $9 \mathrm{mg} / \mathrm{mL}$. In another study it was reported that alcoholic extracts of Lentinula edodes scavenged up to $50 \%$ at $6.43 \mathrm{mg} / \mathrm{mL}$ (Reis et al., 2012). The present findings indicate that Lentinula edodes PKSR14 has high radical scavenging activity $(61.33 \%)$ which may be primarily due to the presence of various natural antioxidants in the crude extracts.

Moisture content and water activity affect the texture and participate in the short shelf life of fruiting bodies (Kalač, 2009). The macronutrient profile, in general, revealed that Lentinula edodes PKSR14 has higher amount of protein and carbohydrate than fat. This high protein and carbohydrate with a low fat characteristic of the wild edible mushrooms has been reported previously (Diez and Alvarez, 2001; Agrahar-Murugkar and Subbulakshmi, 2005) which makes them suitable as health promoting foods. However, the differences between the nutrient composition of Lentinula edodes PKSR14 as revealed in the present study and that of other Lentinula edodes reported across the world (Manzi et al., 1999) can probably be attributed to a number of environmental and genetic conditions that guide the growth of this mushroom species (Manzi et al., 2001).

Anti-inflammatory activity of metabolite extracts of medicinal plants has been studied widely (Leelaprakash \& Mohan Dass, 2011). It has been reported that the presence of tannins (Mota et al., 1985), flavonoids (Huang et al., 2009), triterpenoids (Della et al., 1994) and phenolic compounds (Song et al., 2008) in the extracts are responsible for anti-inflammatory activity. In the present investigation, it was seen that the extracts of Lentinula edodes PKSR14 showed potential anti-inflammatory capacity in-vitro, suggesting that it could be regarded as a potential source of natural antiinflammatory agents.

The unique and novel mushroom specimens from the selected locations, which are yet to be fully explored, have been shown to be rich sources of bioactive compounds, antioxidants, anti-inflammatory substances and nutrients that make them potential candidates for further development as functional foods. Technological advancements such as GIS and remote sensing based open access platforms like Bhuvan and Agriculture Planning and Information Bank (APIB), developed under the Space Research programme have been successfully tested in the present investigation to locate the natural habitats of the wild edible mushrooms which are sold extensively in the rural markets of Meghalaya. The explored technology offers scope to map the wild non-woody forest resource which can have application in efforts designed for conservation, bioprospection and cultivation of such resources.

\section{ACKNOWLEDGMENTS}

We have used the Land Use/Land Cover information on our research work from Natural Resources Census Project of National Remote Sensing Centre (NRSC), ISRO, Hyderabad, India. The financial support received as research grant from Department of Science \& Technology, Govt of India is gratefully acknowledged.

\section{RESUMEN}

Mapas basados en GIS de Lentinula edodes, biometabolitos y actividad antiinflamatoria de los hongos silvestres comestibles de los bosques tropicales "bosque 
sagrado" de Meghalaya, India. La rica biodiversidad del estado de Meghalaya, India situado en los reinos de los hotspots mega-biodiversidad es el hogar de numerosas especies de macro hongos silvestres comestibles que se utilizan ampliamente por la población étnica micofílica como parte de su alimentación y medicina tradicional. Sin embargo, la pérdida de hábitat debido a la deforestación y el cambio climático está destruyendo la población natural de estos hongos, que agotan su disponibilidad para las poblaciones locales. En la presente investigación, se utilizó el SIG para la búsqueda guiada de hábitat usando Lentinula edodes como especie representativa en la cartografía de los hábitats de macrohongos silvestres comestibles de la región de estudio. Alrededor de cuatro mil ejemplares de distinto tipo morfológico fueron muestreados según su disponibilidad en los mercados tradicionales y los "sacred grove" (bosques sagrados) lo que indicó la presencia de diez géneros comunes pertenecientes a nueve familias de setas silvestres comestibles. Perfiles nutricionales de las especies representativas Lentinula edodes se llevaron a cabo mediante la evaluación de su humedad, grasa total, proteína cruda y contenido de carbohidratos. Del mismo modo, la determinación de componentes bioactivos se realizó por estimación de fenoles totales, flavonoides, ácido ascórbico, $\beta$-caroteno y licopeno. La bioactividad de los extractos de setas se estudió mediante la captación de radicales DPPH y el ensayo de estabilización de la membrana de glóbulos rojos de la sangre humana (hRBC). Los resultados de estudios de perfiles nutricionales y actividad biológica en hongos comestibles revelan que es una fuente rica en nutrientes esenciales y antioxidantes. La presente investigación ha intentado con éxito explorar las tecnologías de teledetección y SIG (Sistema de Información Geográfica) para predecir el hábitat natural de los hongos silvestres comestibles de Meghalaya, India que creemos dará lugar a la generación de un mapeo de los recursos forestales no madereros, específicamente de hongos, en el futuro cercano.

Palabras clave: hongos silvestres comestibles, caracterización, tribus étnicas, sistema SIG, mapeo, los bosques "bosque sagrado", Lentinula edodes.

\section{REFERENCES}

Agrahar-Murugkar, D., \& Subbulakshmi, G. (2005). Nutritional value of edible wild mushrooms collected from the Khasi hills of Meghalaya. Food Chemistry, 89(4), 599-603.

Agriculture Planning and Information Bank (APIB) of the East Khasi Hills District of Meghalaya, jointly developed by the North Eastern Space Applications Centre (NESAC) in collaboration with the Department of Agriculture, Government of Meghalaya. http:// megapib.nic.in. Accessed 04/01/2013.
Association of Official Analytical Chemists (AOAC). 1995. Official Methods of Analysis, 16th edition. Arlington VA: Association of Official Analytical Chemists.

Austin, M. P. (2002). Spatial prediction of species distribution: an interface between ecological theory and statistical modelling. Ecological Modelling, 157(2/3), 101-118.

Barua, P., Adhikary, R. K., Kalita, P., Bordoloi, D., Gogoi, P., Singh, R. S., \& Ghosh, A. C. (1998). Wild edible mushrooms of Meghalaya. Ancient Science of Life, 17(3), 190.

Barros, L., Calhelha, R. C., Vaz, J. A., Ferreira, I. C., Baptista, P., \& Estevinho, L. M. (2007). Antimicrobial activity and bioactive compounds of Portuguese wild edible mushrooms methanolic extracts. European Food Research and Technology, 225(2), 151-156.

Barros, L., Cruz, T., Baptista, P., Estevinho, L. M., \& Ferreira, I. C. (2008a). Wild and commercial mushrooms as source of nutrients and nutraceuticals. Food and Chemical Toxicology, 46(8), 2742-2747.

Barros, L., Venturini, B. A., Baptista, P., Estevinho, L. M., \& Ferreira, I. C. (2008b). Chemical composition and biological properties of Portuguese wild mushrooms: a comprehensive study. Journal of Agricultural and Food Chemistry, 56(10), 3856-3862.

Bhagobaty, R. K., \& Joshi, S. R. (2011). Fungal endophytes of five medicinal plants prevalent in the traditionally preserved 'Sacred forests' of Meghalaya, India. Forest Science and Technology, 7(4), 151-154.

Blois, S. (1958). Antioxidants determination by the use of a stable free radical. Nature, 181, 1199-1200.

Cheung, L. M., Cheung, P. C., \& Ooi, V. E. (2003). Antioxidant activity and total phenolics of edible mushroom extracts. Food Chemistry, 81(2), 249-255.

Della Loggia, R., Tubaro, A., Sosa, S., Becker, H., \& Isaac, O. (1994). The role of triterpenoids in the topical anti-inflammatory activity of Calendula officinalis flowers. Planta Medica, 60(06), 516-520.

Diez, V. A., \& Alvarez, A. (2001). Compositional and nutritional studies on two wild edible mushrooms from northwest Spain. Food Chemistry, 75, 417-422.

Ferreira, I. C., Baptista, P., Vilas-Boas, M., \& Barros, L. (2007). Free-radical scavenging capacity and reducing power of wild edible mushrooms from northeast Portugal: Individual cap and stipe activity. Food Chemistry, 100(4), 1511-1516.

Franklin, J. (1998). Predicting the distribution of shrub species in southern California from climate and terrain derived variables. Journal of Vegetation Science, 9(5), 733-748.

Gezer, K., Duru, M. E., Kivrak, I., Turkoglu, A., Mercan, N., Turkoglu, H., \& Gulcan, S. (2006). Free-radical scavenging capacity and antimicrobial activity of 
wild edible mushroom from Turkey. African Journal of Biotechnology, 5, 1924-1928.

Govindappa, M., Sadananda, T. S., Channabasava, R., \& Raghavendra, V. B. (2011). In vitro anti-inflammatory, lipoxygenase, xanthine oxidase and acetycholinesterase inhibitory activity of Tecoma stans (L.) Juss. Ex Kunth. International Journal of Pharma \& Bio Sciences, 2(2), 275-285.

Harsh, N. S. K., \& Joshi, K. (2008). Mushrooms: The Vegetable of the Future. India. Science and Technology. S\&T for Rural India and Inclusive Growth. http:// ssrn.com/abstract=1474175. Accessed 04/01/2012.

Hobbs, C. R. (1995). Medicinal mushrooms: an exploration of tradition, healing and culture. Santa Cruz, CA.: Botanica Press.

Huang, Y. C., Hwang, T. L., Chang, C. S., Yang, Y. L., Shen, C. N., Liao, W. Y., Chen, S. C., \& Liaw, C. C. (2009). Anti-inflammatory flavonoids from the rhizomes of Helminthostachys zeylanica. Journal of Natural Products, 2(7), 1273-1278.

Iverson, L. R., Prasad, A., \& Schwartz, M. W. (1999). Modeling potential future individual tree-species distributions in the eastern United States under a climate change scenario: a case study with Pinus virginiana. Ecological Modelling, 115(1), 77-93.

Joshi, S., Vishwakarma, M. P., Mahar, R., \& Bhatt, R. P. (2013). Medicinally important and edible species of genus Lactarius from Garhwal Himalaya, India. Mycosphere, 4(4), 714-720.

Kalač, P. (2009). Chemical composition and nutritional value of European species of wild growing mushrooms: A review. Food Chemistry, 113(1), 9-16.

Khaund, P., \& Joshi, S. R. (2013). Wild edible macrofungal species consumed by the Khasi tribe of Meghalaya, India. Indian Journal of Natural Products and Resources, 4(2), 197-204.

Klein, B. P., \& Perry, A. K. (1982). Ascorbic acid and vitamin A activity in selected vegetables from different geographical areas of the United States. Journal of Food Science, 47, 941-945.

Kranabetter, J. M., Trowbridge, R., Macadam, A., McLennan, D., \& Friesen, J. (2002). Ecological descriptions of pine mushroom (Tricholoma magnivelare) habitat and estimates of its extent in northwestern British Columbia. Forest Ecology and Management, 158(1), 249-261.

Leelaprakash, G., \& Dass, S. M. (2011). Invitro antiinflammatory activity of methanol extract of Enicostemma axillare. International Journal of Drug Development and Research, 3(3), 189-196.

Manzi, P., Gambelli, L., Marconi, S., Vivanti, V., \& Pizzoferrato, L. (1999). Nutrients in edible mushrooms: an inter-species comparative study. Food Chemistry, 65(4), 477-482.
Manzi, P., Aguzzi, A., \& Pizzoferrato, L. (2001). Nutritional value of mushrooms widely consumed in Italy. Food Chemistry, 73(3), 321-325.

Mota, M. L., Thomas, G., \& Barbosa, F. J. M. (1985). Anti-inflammatory actions of tannins isolated from the bark of Anacardium occidentale L. Journal of Ethnopharmacology, 13(3), 289-300.

Nagata, M., \& Yamashita, I. (1992). Simple method for simultaneous determination of chlorophyll and carotenoids in tomato fruit. Nippon Shokuhin Kogyo Gakkaishi, 39, 925-928.

Ogawa, M. (1976). Microbial ecology of mycorrhizal fungus Tricholoma matsutake (Ito et Imai) Sing. in pine forest. II. Mycorrhiza formed by Tricholoma matsutake. Bulletin of the Government Forest Experiment Station Tokyo, 278, 21-80.

Online Interactive Map Bhuvan-Thematic Services, LULC-50K map of East Khasi hills district, Meghalaya 2005-06 and 2011-12 /NRC, NRSC/ISRO - India, viewed 04 January 2013, <http://bhuvan-noeda.nrsc. gov.in/theme/thematic/theme.php>.

Palanisamy, U. D., Ling L. T., Manaharan, T., \& Appleton, D. (2011). Rapid isolation of geraniin from Nephelium lappaceum rind waste and its anti-hyperglycemic activity. Food Chemistry, 127, 21-27.

Park, Y. K., Koo, M. H., Ikegaki, M., \& Contado, J. L. (1997). Comparison of the flavonoid aglycone contents of Apis mellifera propolis from various regions of Brazil. Arquivos de Biologia e Technologia, 40, 97-106.

Peltoniemi, J. I., Kaasalainen, S., Naranen, J., Rautiainen, M., Stenberg, P., Smolander, H., Smolander, S., \& Voipio P. (2005). BRDF measurement of understory vegetation in pine forests: dwarf shrubs, lichen, and moss. Remote Sensing of Environment, 94(3), 343-354.

Purkayastha, R. P., \& Chandra, A. (1985). Manual of Indian Edible Mushrooms. New Delhi: Today and Tomorrow's Publication.

Rao, A. V., \& Agarwal, S. (1999). Role of lycopene as antioxidant carotenoid in the prevention of chronic diseases: a review. Nutrition Research, 19(2), 305-323.

Reis, F. S., Martins, A., Barros L., \& Ferreira, I. C. (2012). Antioxidant properties and phenolic profile of the most widely appreciated cultivated mushrooms: A comparative study between in vivo and in vitro samples. Food and Chemical Toxicology, 50(5), 1201-1207.

Sabota, C. (1996). Strain of shiitake mushroom Lentinula edodes (Berk.) Pegler and wood species affect the yield of shiitake mushrooms. HortTechnology, 6(4), 388-393.

Saija, A., Scalese, M., Lanza, M., Marzullo, D., Bonina, F., \& Castelli, F. (1995). Flavonoids as antioxidant 
agents: importance of their interaction with biomembranes. Free Radical Biology and Medicine, 19(4), 481-486.

Sies, H., \& Stahl, W. (1995). Vitamins E and C, betacarotene, and other carotenoids as antioxidants. The American Journal of Clinical Nutrition, 62(6), 1315S-1321S.

Singleton, V. L., \& Rossi, J. A. (1965). Colorimetry of total phenolics with phosphomolybdic-phosphotungstic acid reagents. American Journal of Enology and Viticulture, 16(3), 144-158.

Skidmore, A. K., Watford, F., Luckananurug, P., \& Ryan, P. J. (1996). An operational GIS expert system for mapping forest soils. Photogrammetric Engineering and Remote Sensing, 62(5), 501-511.

Svrcek, M., \& Coxon, D. (1975). A color guide to familiar mushrooms and fungi. London: Octopus Books Limited.

Tanti, B., Gurung, L., \& Sarma, G. C. (2011). Wild edible fungal resources used by ethnic tribes of Nagaland,
India. Indian Journal of Traditional Knowledge, 10(3), 512-515.

Tripathi, R. S., Pandey, H. N., Barik, S. K., \& Kumar, A. (2005). State of Environment Report, Meghalaya, Dept. of Environment and Forests, Govt of Meghalaya. Meghalaya, India.

Wilson, J. X. (2005). Regulation of vitamin C transport. Annual Review of Nutrition, 25, 105-125.

Yaltirak, T., Aslim, B., Ozturk, S., \& Alli, H. (2009). Antimicrobial and antioxidant activities of Russula delica Fr. Food and Chemical Toxicology, 47(8), 2052-2056.

Yang, X., Skidmore, A. K., Melick, D. R., Zhou, Z., \& $\mathrm{Xu}$, J. (2006). Mapping non-wood forest product (matsutake mushrooms) using logistic regression and a GIS expert system. Ecological Modelling, 198(1), 208-218.

Zaniewski, A. E., Lehmann, A., \& Overton, J. M. (2002). Predicting species spatial distributions using presence-only data: a case study of native New Zealand ferns. Ecological Modelling, 157(2), 261-280. 
